http://jmscr.igmpublication.org/home/

ISSN (e)-2347-176x ISSN (p) 2455-0450

crossref DOI: https://dx.doi.org/10.18535/jmscr/v8i11.83

Journal Of Medical Science And Clinical Research

IGM Publication

An Official Publication of IGM Publication

\title{
Study on Serum Vitamin D Levels in Patients with Bronchial Asthma
}

\author{
Authors \\ Dr Vaddadi Navya Sri ${ }^{1}$, Dr D Radha Krishnan ${ }^{2}$, Dr Yarraguntla Pranathi ${ }^{3}$ \\ ${ }^{2}$ Professor, Department of General Medicine \\ ${ }^{1,3}$ Post Graduates, Department of General Medicine \\ King George Hospital, Visakhapatnam, Andhra Pradesh, India
}

\begin{abstract}
Background: Asthma represents one of the most common chronic diseases and is a major public health problem worldwide. The innate and adaptive immune systems play an important role in the pathogenesis of asthma. Vitamin D has several effects on the innate and adaptive immune system that might be relevant in the primary prevention of asthma and modulation of severity of asthma exacerbations.

Materials and Methods: This is a cross sectional observational study done for 10 months in the Department of General Medicine, King George Hospital, Visakhapatnam, from January 2020 to october 2020. A total of 50 patients of bronchial asthma and 50 controls

Results: The mean serum vitamin D level of bronchial asthma patients were $23 \pm 8 \mathrm{ng} / \mathrm{ml}$, among controls it was $30 \pm 8 \mathrm{ng} / \mathrm{ml}$. This analysis significantly shows that mean serum vitamin D level was low in asthma as compared with controls

Conclusion: Our study concludes that hypovitaminosis D was highly prevalent among patients of bronchial asthma as compared to general population.
\end{abstract}

\section{Introduction}

Vitamin D is responsible for intestinal absorption of calcium and phosphate. Dietary sources include liver, fish, egg, fish liver oil and dietary supplements. As very few foods contain vitamin $\mathrm{D}$, sunlight exposure is the primary determinant of Vitamin D status in humans. The bone health consequences of vitamin D deficiency are well established, however, other disorders have also been linked to vitamin D insufficiency, including asthma. New research has identified Vitamin D also play vital for respiratory health. Due to its anti-inflammatory properties, 1,25 (OH)D may be very important in people with asthma. Vitamin D receptors expressed in multiple lung cell and acts to protection from asthma by several mechanisms including promoting lung immunity, decreasing inflammation and slowing cell cycling hyperplasia, The objective of this study was to systematically review the evidence for an association between low serum levels of vitamin $\mathrm{D}$ and presence of asthma.

\section{Aims and Objectives}

To determine serum vitamin $\mathrm{D}$ level in patients of bronchial asthma and compare it with controls.

\section{Materials and Methods}

This is a cross sectional observational study done for 1o months from January 2020 to August 2020 in the Department of General Medicine, King George Hospital. This study included patients of 
age 18-60 years with diagnosis of bronchial asthma on basis of clinical and radiological signs and symptom with spirometric criteria (FEV1/FVC <0.7 \%, FEV1 <80\%) with significant bronchodilatation.

Controls are healthy subjects of age $18-60$ years free from any disease and morbidity.

Following investigations were done for all the patients:

1. Chest $X$ ray PA view

2. Spirometry

3. Serum vitamin $\mathrm{D}$ ( $25 \mathrm{OH}$ vitamin $\mathrm{D}$ )

\section{Inclusion Criteria}

GROUP A : age 18-60 years

Patients with bronchial asthma

GROUP B: age 18-60 years

Healthy subjects free from any disease and morbidity.

\section{Exclusion Criteria}

Following patients were excluded from the study:

1. All known cases of chronic kidney disease, osteomalacia.
2. Patients age $<18$ years, $>60$ years

\section{Results}

\section{Age and Sex Distribution}

In our study 100 subjects included with age of 1860 years. All subjects divided into controls and cases, out of which 50 were controls including 31 males and 19 females, 50 were cases including 23 males 28 females.

\section{Frequency distribution of serum 25 hydroxy vitamin $D$ in study group}

The mean serum vitamin D of asthma patients was $23 \pm 8$ and among controls it was $31 \pm 8$. This analysis significantly shows that mean serum vitamin D levels were low in patients with bronchial asthma as compared with controls.

\begin{tabular}{|l|c|c|}
\hline Study group & $\begin{array}{c}\text { CASES } \\
\text { Group A }\end{array}$ & $\begin{array}{c}\text { CONTROLS } \\
\text { Group B }\end{array}$ \\
\hline $\begin{array}{l}\text { Mean serum 25OH } \\
\text { vitamin D ng/ml }\end{array}$ & $23 \pm 8 \mathrm{ng} / \mathrm{ml}$ & $31 \pm 8 \mathrm{ng} / \mathrm{ml}$ \\
\hline
\end{tabular}

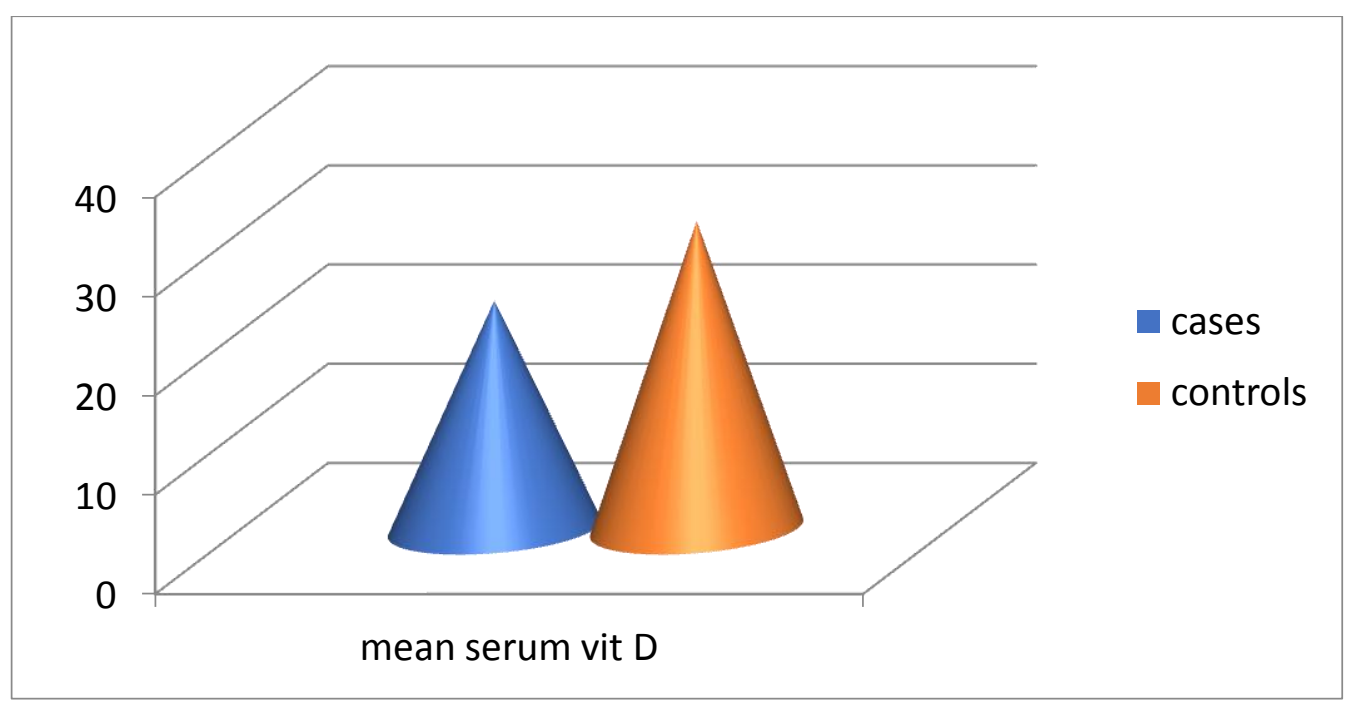

\section{Discussion}

Bronchial asthma is a complex inflammatory disease, it is a clinical syndrome characterised by increased responsiveness of tracheobronchial tree to a variety of stimuli.
Vitamin D receptors (VDRs) are widely distributed in respiratory epithelial cells and immune cells (B cells, T cells, macrophages, monocytes). serum $25(\mathrm{OH}) \mathrm{D}$ is used as a marker of vitamin D clinically. The activating enzyme 1 
alpha hydroxylase is expressed by respiratory epithelial cells and converts inactive $25(\mathrm{OH}) \mathrm{D}$ to active $1,25(\mathrm{OH}) \mathrm{D}$ it binds to VDRs and interacts with various immune cells. In addition, vitamin D inhibits IL- 4 mediated expression of IL-13 and proinflammatory cytokines IL-17, accelerates T regulatory cell secretion

Vitamin D causes increased production of cathelicidin which is a antimicrobial peptide through these mechanisms vitamin D act as antiinflammatory and anti microbial in respiratory tract so as to prevent recurrent infections and inflammation therefore decreasing the exacerbation of asthma

In this study, the incidence of bronchial asthma is more common in females than males.

In this study mean serum vitamin D levels are low in patients with bronchial asthma as compared to controls, which was similar to study done by Mohamed yousry A. Shahin, ahmed A. El lawah, Ayman Amin , Islam A.H.El-Tawil ${ }^{1}$

Salauddin, nafees A. Khan, Md. Shameem, Rakesh bhargava

\section{Conclusion}

This cross sectional study shows that hypovitaminosis D was highly prevalent among bronchial asthma patients as compared to general population. Study suggests that periodic screening of serum vitamin D and supplementation should be considered in routine care in patients with bronchial asthma. They are educated regarding the importance of physical activity, exposure to sunlight and use of diet rich of vitamin D

\section{Limitations}

The study is done in a limited number of patients. Results may vary when done in a large number of subjects.

\section{Source of Support: None}

Conflict of Interest: None

\section{References}

1. Mohamed yousry A. Shahin , ahmed A. El- lawah, Ayman Amin, Islam A.H.ElTawil ${ }^{1}$ jan 2017

2. Salauddin, nafees A. Khan, Md. Shameem, Rakesh bhargava oct 2016

3. Gomez AC, Naves DM, Rodriguez GM, Fernandez Martin JL, Cannata Andia JB. [Review of the concept of vitamin D "sufficiency and insufficiency"]. Nefrologia \% 2003; 23Suppl 2:73 -7 2003.

4. Food and Nutrition Board. Institute of Medicine. Dietary reference intakes: water, potassium, sodium, chloride, and sulfate. Washington, DC:National Academy Press; 2004.

5. Adams JS, Hewison M. Unexpected actions of vitamin D: new perspectives on the regulation of innate and adaptive immunity. Nat Clin Pract Endocrinol Metab 2008;4:80-90.

6. Global initiative for asthma : GINA report, global strategy for asthma management and prevention- revised 2010

7. S.J .Niruban, K. Alagiakrishnan, J. Beach, et al. association between vitamin $\mathrm{D}$ and respiratory outcomes in adolescents and adults 2015 , pp.1-33. 